\title{
Interpretation of benthic foraminiferal stable isotopes in subtidal estuarine environments
}

\author{
P. Diz ${ }^{1, *}$, F. J. Jorissen ${ }^{1}$, G. J. Reichart ${ }^{2,3}$, C. Poulain ${ }^{4}$, F. Dehairs ${ }^{5}$, E. Leorri ${ }^{1,6, * *}$, and Y.-M. Paulet ${ }^{4}$ \\ ${ }^{1}$ Laboratoire des Bio-Indicateurs Actuels et Fossiles (BIAF), UPRES EA 2644, Université d'Angers, 2, Boulevard Lavoisier, \\ 49045 Angers Cedex, and LEBIM, Ker Chalon, 85350 Ile D'Yeu, France \\ ${ }^{2}$ Faculty of Geosciences, Organic Geochemistry, Utrecht University, Budapestlaan 4, Utrecht, 3584 CD, The Netherlands \\ ${ }^{3}$ Alfred Wegener Institute for marine and polar research, Bremerhaven, Germany \\ ${ }^{4}$ LEMAR, CNRS/UBO/IRD 6539, Institut Universitaire Européen de la Mer, Place Nicolas Copernic, \\ 29280 Plouzané, France \\ ${ }^{5}$ Faculty of Sciences, Vrije Universiteit, Pleinlaan 2, 1050, Brussels \\ ${ }^{6}$ Centro de Geologia, Faculdade de Ciências da Universidade de Lisboa, Campo Grande, 1749-016 Lisboa, Portugal \\ *Unidade de Geologia Marinha, Laboratório Nacional de Energia e Geologia, Estrada da Portela, Zambujal, Amadora \\ 2721-866, Portugal \\ *** Department of Geological Sciences, East Carolina University, Graham Building 103B, Greenville NC, 27858, USA
}

Received: 7 July 2009 - Published in Biogeosciences Discuss.: 24 July 2009

Revised: 7 October 2009 - Accepted: 29 October 2009 - Published: 13 November 2009

\begin{abstract}
Here we present a novel approach for the interpretation of stable isotope signatures recorded in benthic foraminifera from subtidal estuarine environments. The stable isotopic composition $\left(\delta^{18} \mathrm{O}\right.$ and $\left.\delta^{13} \mathrm{C}\right)$ of living Ammonia tepida and Haynesina germanica is examined at four stations in the Auray River estuary (Gulf of Morbihan, France) sampled in two contrasting seasons, spring 2006 and winter 2007. Comparing benthic foraminiferal $\delta^{18} \mathrm{O}$ measurements with theoretical oxygen isotopic equilibrium values, calculated on the basis of water temperature and salinity measurements in the upper and lower estuary, i.e., T-S- $\delta^{18} \mathrm{O}_{e q}$. diagrams, strongly suggests that foraminiferal faunas sampled at the four stations calcified during different periods of the year. This interpretation can be refined by using the benthic foraminiferal $\delta^{13} \mathrm{C}$, which is mainly determined by the mixing of sea and river water. In the upper estuary foraminifera mainly calcified in early spring and winter, whereas in the lower estuary calcification mainly took place in spring, summer and autumn. This new method provides insight into the complexity of estuarine benthic foraminiferal stable isotope records. In addition, it can also be used to obtain new information on preferred calcification periods of benthic foraminiferal taxa in different parts of the estuary.
\end{abstract}

Correspondence to: P. Diz

(paula.diz@ineti.pt)

\section{Introduction}

Benthic foraminifera from shallow water settings can be successfully used as proxies of environmental variables (e.g., Redois and Debenay, 1996; Debenay et al., 2000; Duchemin et al., 2005; Murray, 2006) or as a bio-indicators of the ecological status of the environment (e.g., Alve, 1995; Debenay et al., 2001; Morvan et al., 2004; Armynot du Châtelet et al., 2004; Platon et al., 2005; Le Cadre and Debenay, 2006; Bouchet et al., 2007; Leorri et al., 2009). However, the use of foraminifera in such settings is often hampered by extreme spatial and temporal variability of the foraminiferal faunas. Detailed studies of benthic foraminiferal faunas from intertidal and subtidal environments show a high degree of patchiness (Hohenegger et al., 1993; Murray and Alve, 2000; Swallow, 2000; Hippensteel et al., 2000; Buzas et al., 2002; Morvan et al., 2006). High-frequency studies (over extended periods, i.e., more than a year) also indicate high temporal variability of the faunas (Boltovskoy and Lena, 1969; Cearreta, 1988; Swallow, 2000; Murray, 2000; Alve and Murray, 2001; Buzas et al., 2002; Morvan et al., 2006). This spatial and temporal variability concerns the overall faunal density as well as the density of individual taxa, both varying in unpredictable ways.

Subtidal estuarine environments at mid to high latitudes are affected by strong temperature and salinity variations throughout the year. The impact of these parameters may

Published by Copernicus Publications on behalf of the European Geosciences Union. 
vary between different parts of the estuary with salinity changes being more important in the upper parts than in the lower parts. Because both temperature and $\delta^{18} \mathrm{O}_{w}$ (mainly related to salinity) have a major impact on $\delta^{18} \mathrm{O}$ of carbonate shells, large temporal variations in these parameters make it difficult to interpret benthic foraminiferal $\delta^{18} \mathrm{O}$ in subtidal estuarine environments. Salinity also influences the carbon isotopic composition of foraminiferal shells because dissolved inorganic carbon in river water has generally lower $\delta^{13} \mathrm{C}_{\text {DIC }}$ values compared to open ocean waters (e.g., Bauch et al., 2004). In addition, the degradation of isotopically light organic carbon may locally deplete the $\delta^{13} \mathrm{C}$ signature recorded in the carbonate of the benthic foraminiferal shells in relation to bottom water $\delta^{13} C_{\text {DIC }}$ (e.g., Chandler et al., 1996). The specific features of these environments, together with the complexity of ecological factors outlined above (i.e., patchiness and strong variability in reproductive periods) complicate the applicability of foraminiferal stable oxygen isotopes for paleoenvironmental reconstructions.

In the present study we aim at better understanding the parameters influencing oxygen and carbon isotopic composition of subtidal estuarine benthic foraminifera from the Auray River estuary (Gulf of Morbihan, France). The $\delta^{18} \mathrm{O}$ and $\delta^{13} \mathrm{C}$ isotopic composition of living specimens of $\mathrm{Am}$ monia tepida (Cushman) and Haynesina germanica (Ehrenberg) is documented at four stations sampled during spring 2006 and winter 2007. Foraminiferal stable isotope signatures are difficult to interpret because of the substantial variations in bottom water temperature and salinity throughout the year. Here, we propose a novel approach to interpret stable isotopes in such environments based on the comparison of foraminiferal isotopic measurements with the annual temperature and salinity cycle in different parts of the estuary. This approach provides valuable information about the timing of foraminiferal calcification and will improve our understanding of stable isotope records based on fossil estuarine assemblages.

\section{Study area}

The Auray River estuary is located north of the Gulf of Morbihan (Southern Brittany, France, Fig. 1), a semi-enclosed embayment. Fresh water input to the estuary mainly comes from two rivers: Loc'h and Bono (Fig. 1). These waters mix with marine waters of the Gulf of Morbihan originating from the Bay of Quiberon and entering through the Straits of Port Navalo (Fig. 1). The mean tidal range varies between $2.90 \mathrm{~m}$ and $4.10 \mathrm{~m}$. The sediments in the outer areas of the Auray river estuary (e.g., Locmariaquer) are composed of sand with low organic carbon content and are influenced by strong currents, whereas within the Auray estuary, areas with weaker tidal currents are generally enriched in the fine fraction and organic matter (Redois and Debenay, 1996). Phytoplankton production is higher in the lower estuary than in the upper

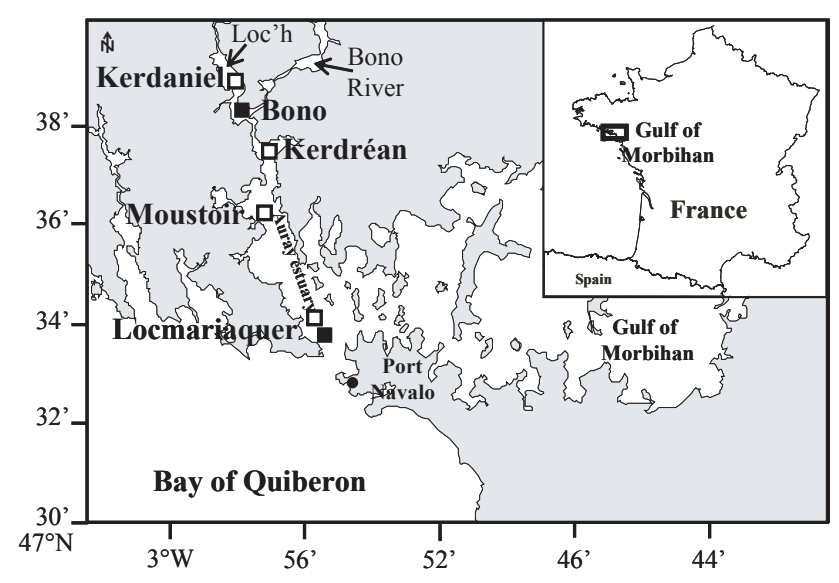

Fig. 1. Setting of the Auray River estuary in the Gulf of Morbihan, foraminiferal sampling sites (white squares) and location of the hydrographic stations (black squares).

estuary and is mainly composed of diatoms (benthic, fresh water or pelagic/oceanic, depending on the season, Paulmier, 1972). In the lower estuary two annual primary production maxima are observed in May and September, whereas in the upper estuary maximum production is restricted to May and June.

\section{Material and methods}

\subsection{Bottom water samples}

Bottom water temperature and salinity were monitored every 10 min between March 2006 and March 2008 with a 600 OMS YSI Sensor located $10 \mathrm{~cm}$ above the bottom at two subtidal stations in the Auray River estuary (Fig. 1), (except for sporadic sensor failure). Daily average values were calculated to characterise the annual cycle of bottom water temperature and salinity in the upper (Bono station) and lower (Locmariaquer station) estuary (Fig. 1).

Salinity and stable isotopes of bottom waters $\left(\delta^{13} \mathrm{C}_{\mathrm{DIC}}\right.$ and $\delta^{18} \mathrm{O}_{w}$ ) were measured on eighteen samples collected at the Bono site (Fig. 1) every $2 \mathrm{~h}$ (except for 2 measurements with $8 \mathrm{~h}$ between samplings) between the 1st and 3rd of March 2007. Water samples from the sediment-water interface were stored in $12 \mathrm{~mL}$ Exetainer vials, poisoned with $20 \mu \mathrm{L}$ of saturated mercuric chloride $\left(\mathrm{HgCl}_{2}\right)$ solution, capped tightly and stored in a cool room until analysis. The $\delta^{18} \mathrm{O}$ of water and $\delta^{13} \mathrm{C}$ of dissolved inorganic carbon (DIC) was measured at the Earth System Science laboratory of Vrije Universiteit Brussel (Belgium) using the protocol described by Gillikin and Bouillon (2007). For $\delta^{18} \mathrm{O}_{\text {water }}$ measurements, $500 \mu \mathrm{L}$ of a water sample and $1000 \mu \mathrm{L}$ pure $\mathrm{CO}_{2}$ from a tank were injected in a $12 \mathrm{~mL}$ helium-flushed headspace vial. After about $48 \mathrm{~h}$ equilibration in a shaker at ambient laboratory temperature $\left(23^{\circ} \mathrm{C}\right), 500 \mu \mathrm{L}$ of $\mathrm{CO}_{2}$ from the headspace was injected 
into the carrier gas stream of a ThermoFinningan Delta XL continuous flow IRMS. Two in-house standards well calibrated against VSMOW were processed with the same protocol. Data are expressed in \%o relative to VSMOW and precision was better than $0.12 \%$ o $(1 \sigma)$ determined by repeated analysis of the standard. For the $\delta^{13} \mathrm{C}_{\text {DIC }}$ measurements, $9.5 \mathrm{~mL}$ of water sample was acidified with $200 \mu \mathrm{L}$ of pure orthoposphoric acid in a $12 \mathrm{~mL}$ helium-flushed headspace vial. After overnight equilibrium, $500 \mu \mathrm{L}$ of the headspace was injected into the carrier gas stream of the IRMS (like in $\delta^{18} \mathrm{O}_{\text {water }}$ analysis). The formula of Miyajima et al. (1995) was used to correct for the partitioning of $\mathrm{CO}_{2}$ between headspace and water phase and to calculate $\delta^{13} \mathrm{C}_{\text {DIC }}$. Data are expressed in \%o relative to VPDB and precision was better than $0.15 \%$ o $(1 \sigma)$ based on 14 analyses of $\mathrm{CO}_{2}$ reference gas.

\subsection{Foraminiferal samples}

\subsubsection{Sampling sites}

Four subtidal stations (Kerdaniel, Kerdréan, Moustoir and Locmariaquer) on a transect along the Auray River estuary were selected for this study (Fig. 1). Kerdaniel $\left(47^{\circ} 38.86^{\prime} \mathrm{N}\right.$, $2^{\circ} 58.30^{\prime} \mathrm{W}$ ) is located in the upper estuary slightly upstream of the Bono River outlet. Kerdréan $\left(47^{\circ} 37.65^{\prime} \mathrm{N}\right.$, $\left.2^{\circ} 57.31^{\prime} \mathrm{W}\right)$ and Moustoir $\left(47^{\circ} 36.14^{\prime} \mathrm{N}, 2^{\circ} 57.45^{\prime} \mathrm{W}\right)$ characterize the middle/upper and middle/lower part of the estuary, respectively, whereas Locmariaquer $\left(47^{\circ} 34.21^{\prime} \mathrm{N}\right.$, $2^{\circ} 56.58^{\prime} \mathrm{W}$ ) is located at the mouth of the estuary and represents the most open marine conditions. The water depth of the sampling sites with respect to the mean tidal level of Port Navalo are $2.3 \mathrm{~m}$ (Kerdaniel), $3.5 \mathrm{~m}$ (Kerdréan), $3 \mathrm{~m}$ (Moustoir) and $1.5 \mathrm{~m}$ (Locmariaquer), all with an error of $\pm 0.5 \mathrm{~m}$. Each station was sampled in spring 2006 (20-21 April or 9 May) and winter 2007 (2 February). During sampling, two sediment cores (replicate samples 01 and 02, a few meters apart) were collected at each station. All samples recovered in February 2007 as well as the samples at Kerdaniel and Moustoir in spring 2006 were recovered with a squared gravity corer $(15 \mathrm{~cm} \times 15 \mathrm{~cm})$. Samples taken in spring 2006 at Kerdréan and Locmariaquer were collected by scuba divers that pushed a pvc core $(9 \mathrm{~cm}$ diameter) into the sediment. In winter 2007, we obtained only a sample of the uppermost centimetre at Locmariaquer. The sediment of Kerdaniel and Moustoir stations is mainly composed of mud with high amounts of plant remains. In Kerdréan, the sediment contains a significant proportion of bioclastic fragments, whereas siliciclastic sands dominate at Locmariaquer. All stations contain variable proportions of meiofauna (mainly polychaeta).

\subsubsection{Sample processing}

Immediately after collection, cores were subsampled into slices of $1 \mathrm{~cm}$ down to $10 \mathrm{~cm}$ depth and subsamples were put into bottles containing ethanol and Rose Bengal ( $1 \mathrm{~g} / \mathrm{l})$. In the laboratory the samples were wet sieved into 63-150 $\mu \mathrm{m}$ and $>150 \mu \mathrm{m}$ size classes, and then stored in $95 \%$ ethanol. Living (Rose Bengal stained) foraminifera from both size fractions were picked from wet samples and stored in micropaleontological slides. We only considered foraminifera alive, when all chambers except the last zero to three were stained bright red/pink. Except for some intervals where the foraminiferal fauna was particularly rich, samples were not split and all living benthic foraminifera were picked and counted. Faunal densities for each core $(0-10 \mathrm{~cm})$ are expressed as the total number of foraminifera standardised to a $50 \mathrm{~cm}^{2}$ surface area.

\subsubsection{Isotopic measurements}

Well preserved individuals of living benthic foraminifera Ammonia tepida and Haynesina germanica were picked from the $>150 \mu \mathrm{m}$ fraction (size range from 150 to $350 \mu \mathrm{m}$ ) of the uppermost centimetre of sediment at the four studied stations, from each replicate core, and for both sampling periods. Stable carbon and oxygen isotope measurements were performed on 6-10 specimens at the stable isotope facilities of Utrecht University using an isotope ratio mass spectrometer (Thermo Finnigan MAT-253) coupled online to an automated carbonate sample preparation device (Kiel III). Results are calibrated against international standard NBS-19 and reported on the Vienna PeeDee Belemnite (VPDB) scale. External reproducibility $(1 \sigma)$ was better than $\pm 0.08 \%$ and $\pm 0.04 \%$ ofor $\delta^{18} \mathrm{O}$ and $\delta^{13} \mathrm{C}$ respectively.

\section{Results}

\subsection{Temperature and salinity}

Temperature values in the Auray river waters are remarkably similar between the upper and lower estuary (Fig. 2a). Lowest water temperatures occur during winter (DecemberMarch), and range from $3.5^{\circ} \mathrm{C}$ to $12^{\circ} \mathrm{C}$. Warmer temperatures during summer (middle of June to end of August) range from 18 to $25^{\circ} \mathrm{C}$. By contrast, the annual salinity cycle in the upper estuary differs substantially from that observed in the lower parts of the estuary. In the upper estuary salinity varies between 18 and 34 whereas in the lower estuary it only varies between 27 and 36 (Fig. 2b). In the upper parts, high salinities coincide with dry months (late spring-summer), but can extend well into the beginning of autumn (OctoberNovember, Fig. 2b). During these periods the salinity gradient between upper and lower estuary is relatively subtle with salinities ranging only from 30 to 36 (Fig. 2b). Lower 

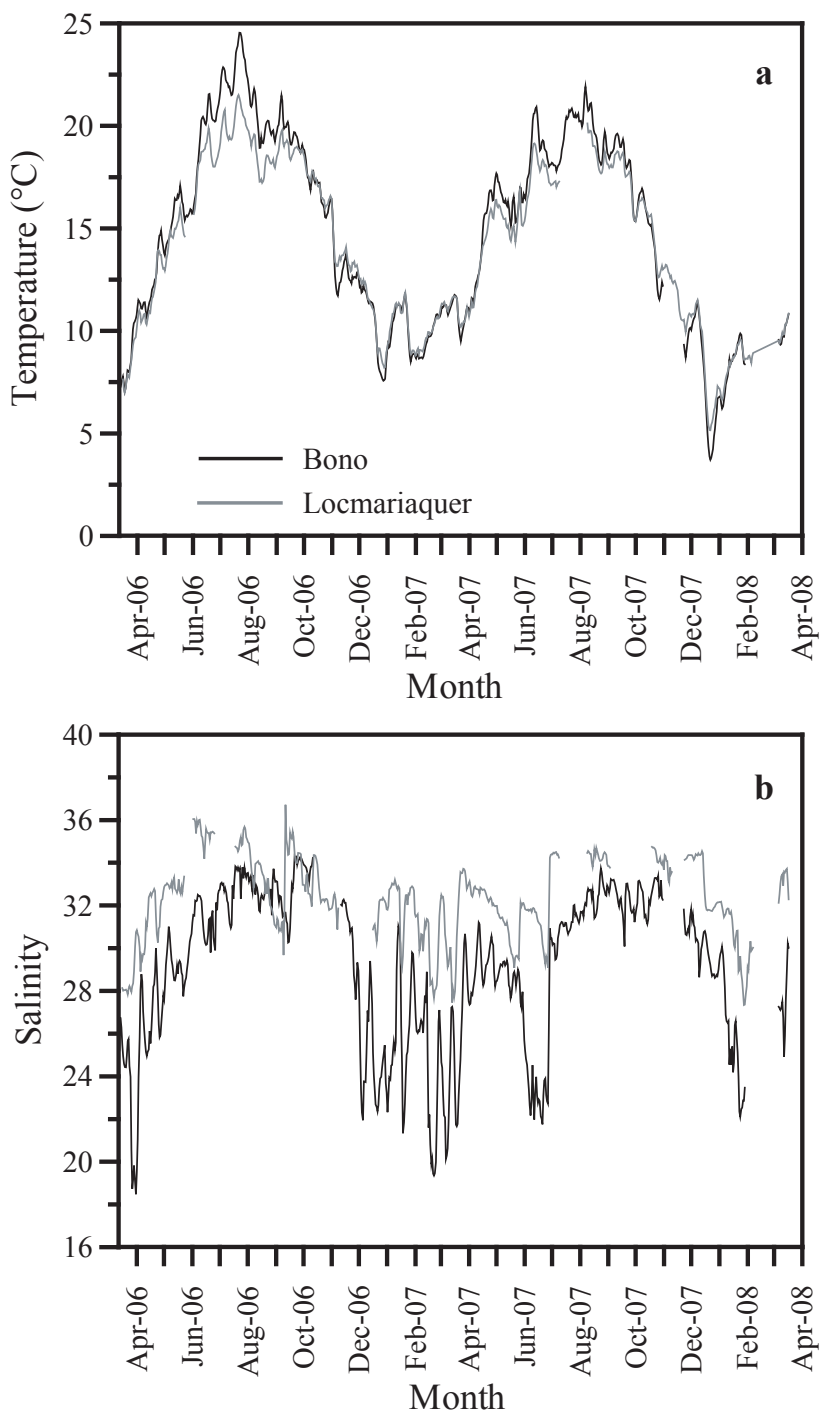

Fig. 2. Bottom water temperature (a) and salinity (b) in Bono (black line) and Locmariaquer (grey line) between March 2006 and March 2008.

salinities are recorded in the upper parts of the estuary during periods of increased precipitation and river discharge in winter, early spring, or during exceptionally rainy periods in summer (e.g., June-July 07, Fig. 2b).

\subsection{Mixing of river and sea water in the Auray river es- tuary and impact on stable carbon and oxygen iso- topic ratios}

Paired measurements of bottom water $\delta^{13} \mathrm{C}_{\mathrm{DIC}}, \delta^{18} \mathrm{O}_{w}$ and salinity at Bono are used here to create a mixing model of sea and river water for the Auray estuary (e.g., Thomas et al., 2000; Polyak et al., 2003; Reinhart et al., 2003; Bauch et al., 2004; Cronin et al., 2005; McGann, 2008). Over the measured salinity range (20-32), both $\delta^{13} \mathrm{C}_{\mathrm{DIC}}$ and $\delta^{18} \mathrm{O}_{w}$ show a

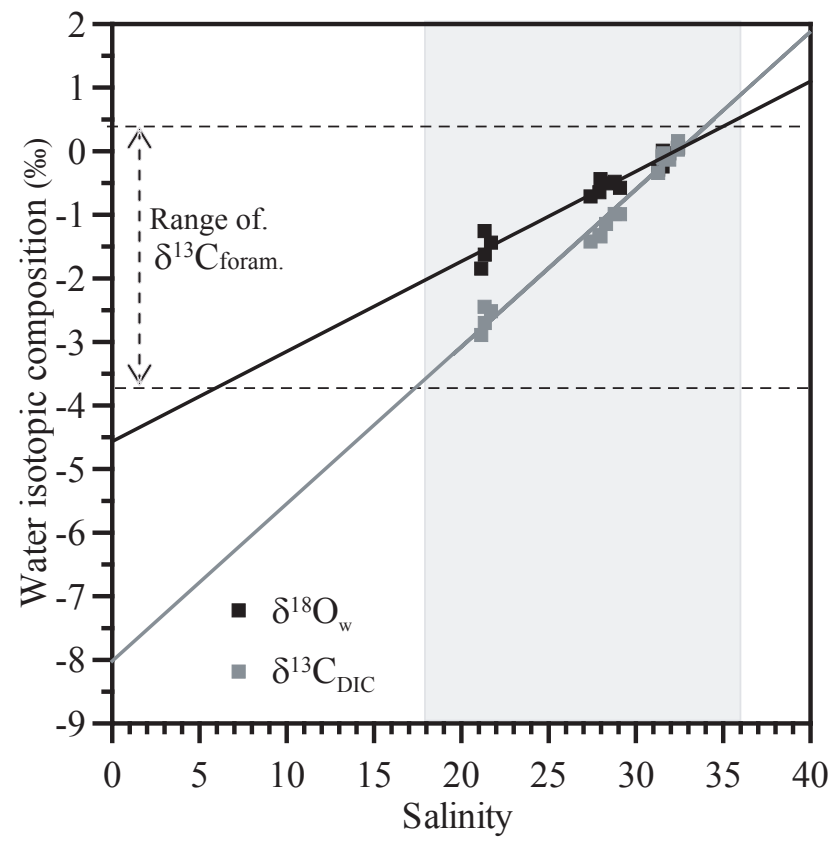

Fig. 3. Mixing line between sea and river waters for $\delta^{18} \mathrm{O}_{w}$ (black) and $\delta^{13} \mathrm{C}_{\text {DIC }}$ (grey) in the Auray estuary. Oxygen isotopic values (VSMOW, black squares) and carbon isotopic values (grey squares, VPDB) are based on samples collected at Bono (Fig. 1) during 3 tidal cycles. The grey band represents maximum and minimum salinity values measured at Bono and Locmariaquer hydrographic stations (Fig. 2b). Horizontal dashed lines indicate the $\delta^{13} \mathrm{C}$ range measured in benthic foraminiferal shells.

strong linear relation with salinity (Fig. 3). Regression lines for $\delta^{13} \mathrm{C}_{\mathrm{DIC}}$ and $\delta^{18} \mathrm{O}_{w}$ to salinity are $\delta^{13} \mathrm{C}_{\mathrm{DIC}}(\% \circ \mathrm{VPDB})$ $=-8.0+0.25 \times$ Salinity $\left(n=18, R^{2}=0.978, p=0.000\right)$ and $\delta^{18} \mathrm{O}_{w}(\%$ 。 VSMOW $)=-4.56+0.14 \times$ Salinity $\left(n=18, R^{2}\right.$ $=0.955, p=0.000)$, respectively. The stable oxygen isotopic composition of the end member (fresh water) is comparable to the oxygen isotope ratios of precipitation in the LoireBretagne catchment area $(-4.8 \% \circ \pm 0.5$, GNIP data for Brest Plouzane, yearly average 1996-2002, International Atomic Energy Agency). The intercept of the $\delta^{13} \mathrm{C}_{\mathrm{DIC}}$ : salinity relationship (-8.0\%o) is comparable to the average of $\delta^{13} \mathrm{C}_{\text {DIC }}$ values in the Rhône-Saône Rivers $(-11.0 \%$, Aucour et al., 2003). Depleted river $\delta^{13} \mathrm{C}_{\mathrm{DIC}}$ values are explained by the reaction of carbon isotopically depleted soil biogenic $\mathrm{CO}_{2}$ and minerals of the basement rocks. Mixing of sea and river water (i.e., salinity) has a much greater impact on $\delta^{13} \mathrm{C}_{\mathrm{DIC}}$ than on $\delta^{18} \mathrm{O}_{w}$. According to the mixing model for the Auray estuary, a change of 15 salinity units leads to a $3.7 \%$ o shift in $\delta^{13} \mathrm{C}_{\mathrm{DIC}}$ and a $2.1 \%$ o shift in $\delta^{18} \mathrm{O}_{w}$.

\subsection{Living benthic foraminiferal faunas}

The abundance of live benthic foraminifera (total number of benthic foraminifera $>63 \mu \mathrm{m}$ per $50 \mathrm{~cm}^{2}$ ) shows large 
Table 1. The $\delta^{18} \mathrm{O}$ and $\delta^{13} \mathrm{C}$ of $A$. tepida and $H$. germanica $(>150 \mu \mathrm{m})$ from the uppermost centimetre of the sediment $(0-1 \mathrm{~cm})$ in the Auray River estuary. Data are reported in \%o in the Vienna PeeDee Belemnite (VPDB) scale. Replicate samples taken from the same area are indicated by 01 or 02 and duplicate measurements of the same sample by numbers into brackets.

\begin{tabular}{|c|c|c|c|c|c|}
\hline Station & Species & Sampling period & Replicate & $\delta^{18} \mathrm{O}(\% \circ)$ & $\delta^{13} \mathrm{C}(\% \circ)$ \\
\hline \multirow[t]{9}{*}{ Kerdaniel } & \multirow[t]{5}{*}{ A. tepida } & \multirow[t]{2}{*}{ April 2006, May 2006} & 01 & 0.985 & -2.483 \\
\hline & & & 02 & 0.641 & -2.840 \\
\hline & & \multirow[t]{3}{*}{ February 2007} & 01 & 0.005 & -2.290 \\
\hline & & & $02(1)$ & 0.243 & -2.787 \\
\hline & & & $02(2)$ & -0.153 & -3.206 \\
\hline & \multirow[t]{4}{*}{ H. germanica } & \multirow[t]{2}{*}{ April 2006, May 2006} & 01 & 0.447 & -3.718 \\
\hline & & & 02 & 0.159 & -2.881 \\
\hline & & \multirow[t]{2}{*}{ February 2007} & 01 & -0.402 & -3.121 \\
\hline & & & 02 & -0.677 & -2.859 \\
\hline \multirow[t]{8}{*}{ Kerdréan } & \multirow[t]{5}{*}{ A. tepida } & \multirow[t]{2}{*}{ April 2006, May 2006} & 01 & 0.565 & -2.123 \\
\hline & & & 02 & 0.067 & -2.118 \\
\hline & & \multirow[t]{3}{*}{ February 2007} & 01(1) & 0.517 & -2.036 \\
\hline & & & $01(2)$ & 0.618 & -2.345 \\
\hline & & & 02 & 0.410 & -2.295 \\
\hline & \multirow[t]{3}{*}{ H. germanica } & \multirow[t]{2}{*}{ April 2006, May 2006} & 01 & 0.132 & -2.674 \\
\hline & & & 02 & 0.104 & -2.544 \\
\hline & & February 2007 & 01 & 0.483 & -2.507 \\
\hline \multirow[t]{9}{*}{ Moustoir } & \multirow[t]{5}{*}{ A. tepida } & \multirow[t]{2}{*}{ April 2006, May 2006} & 01 & 0.317 & -1.464 \\
\hline & & & 02 & 0.720 & -1.812 \\
\hline & & \multirow[t]{3}{*}{ February 2007} & $01(1)$ & 1.002 & -2.316 \\
\hline & & & $01(2)$ & 0.672 & -2.806 \\
\hline & & & 02 & -0.412 & -2.173 \\
\hline & \multirow[t]{4}{*}{ H. germanica } & \multirow[t]{2}{*}{ April 2006, May 2006} & 01 & 0.836 & -0.938 \\
\hline & & & 02 & 0.552 & -1.084 \\
\hline & & \multirow[t]{2}{*}{ February 2007} & 01 & -0.112 & -1.973 \\
\hline & & & 02 & 0.395 & -1.748 \\
\hline \multirow[t]{6}{*}{ Locmariaquer } & \multirow[t]{3}{*}{ A. tepida } & \multirow[t]{2}{*}{ April 2006, May 2006} & 01 & -0.585 & -0.905 \\
\hline & & & 02 & -0.330 & 0.487 \\
\hline & & February 2007 & 01 & 0.042 & -0.873 \\
\hline & \multirow[t]{3}{*}{ H. germanica } & \multirow[t]{2}{*}{ April, May 2006} & 01 & 0.035 & 0.004 \\
\hline & & & 02 & 0.349 & -0.782 \\
\hline & & February 2007 & 01 & 0.333 & -0.524 \\
\hline
\end{tabular}

differences between stations, replicate cores and sampling periods (Fig. 4a). In spring 2006 (April-May), the abundance of live foraminifera is substantially higher at Kerdréan $\left(\sim 400\right.$ individuals per $\left.50 \mathrm{~cm}^{2}\right)$ and at Locmariaquer $(\sim 200$ individuals per $50 \mathrm{~cm}^{2}$ ) than at the other two stations (50 individuals per $50 \mathrm{~cm}^{2}$ ) and foraminifera are mainly concentrated in the two uppermost centimetres of the sediment. In February 2007 the abundance is relatively uniform along the Auray estuary $\left(\sim 300-500\right.$ individuals per $\left.50 \mathrm{~cm}^{2}\right)$, although values are still maximal at the Kerdréan site (Fig. 4a). In contrast to spring 2006, benthic foraminifera are homogenously distributed up to $7-8 \mathrm{~cm}$ of the sediment. The spatial distribution of the two species used in this study is typical of East Atlantic temperate estuaries of the French and Spanish coast (e.g., Redois and Debenay, 1996; Debenay et al., 2000, 2006; Duchemin et al., 2005; Leorri and Cearreta, 2009). Ammo- nia tepida characterizes the upper and middle/upper parts of the estuary (Fig. 4b) whereas Haynesina germanica is represented all along the estuary, although it is more abundant in the upper parts (Fig. 4c). There are some differences in the faunal composition between spring 2006 and winter 2007. The abundance of A. tepida and H. germanica is substantially higher in winter 2007 in the upper and middle/upper estuary. Other characteristic species are Brizalina spathulata (Williamson), Brizalina dilatata (Reuss), Hopkinsina pacifica Cushman, Stainforthia fusiformis (Williamson) in the middle parts of the estuary and Quinqueloculina spp. and Nonion depressulus (Walker and Jacob) in the lower part. Eggerelloides scabrus (Williamson) is found abundant in the middle/upper and lower estuary. Cribroelphidium excavatum (Terquem) is present, although in low proportions, at all stations. 


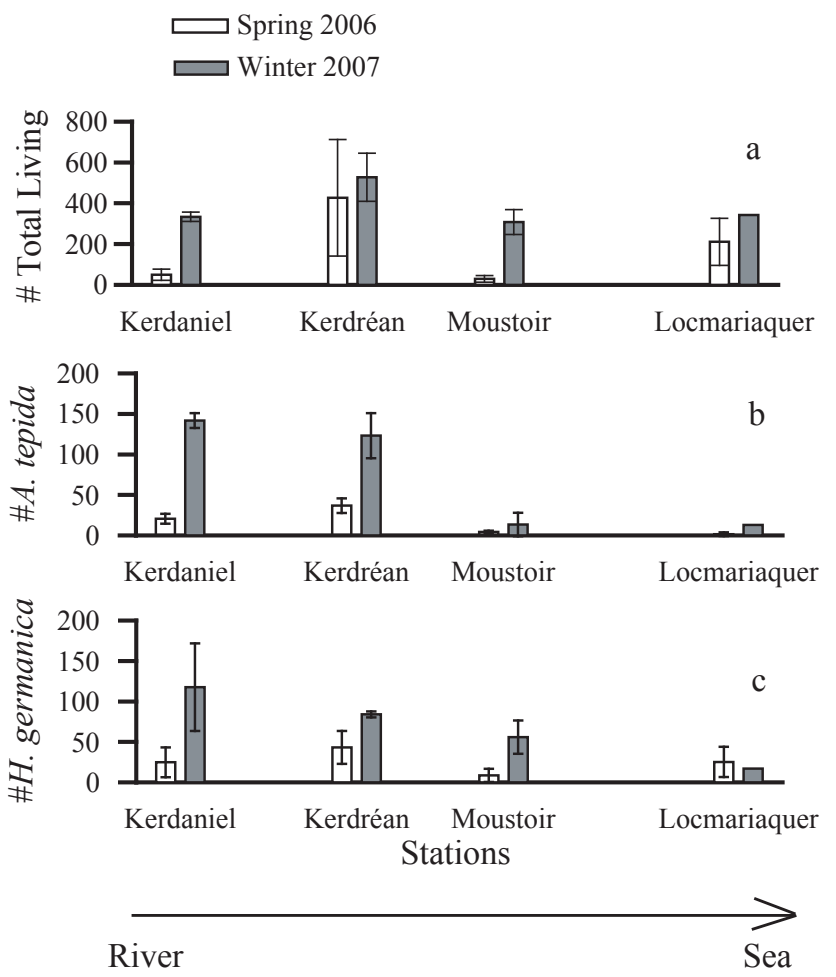

Fig. 4. Mean abundance (white and grey bars) of total living benthic foraminifera (a) and of A. tepida (b) and H. germanica (c). The standard deviation (vertical lines) is based on two replicates for each station. White and grey bars refer to spring 2006 and winter 2007 respectively. Vertical axes represents the number of total live individuals $(>63 \mu \mathrm{m})$ of a particular species found in the core $(0-10 \mathrm{~cm})$ and standardised to $50 \mathrm{~cm}^{2}$ surface area. Note that abundance at Locmariaquer during Winter 2007 does not have a replicate and corresponds to one sample from the uppermost centimetre interval only.

\subsection{Stable carbon and oxygen isotopes of $\boldsymbol{A}$. tepida and H. germanica}

The $\delta^{13} \mathrm{C}$ of $A$. tepida and $H$. germanica increases from the upper to the lower part of the estuary both during winter and spring (Fig. 5, Table 1). The $\delta^{13} \mathrm{C}$ of A. tepida increases on average by $2.4 \%$ in spring 2006 and by $1.9 \%$ in winter 2007 . Average differences in $\delta^{13} \mathrm{C}$ of $H$. germanica between upper and lower estuary are $2.9 \%$ in spring 2006 and $2.5 \%$ in winter 2007. The observed spatial range in benthic foraminiferal $\delta^{13} \mathrm{C}$ (dashed lines in Fig. 3) agrees well with the calculated $\delta^{13} \mathrm{C}_{\mathrm{DIC}}$ gradient caused by mixing of sea and river water (Fig. 3). Unlike carbon isotopes, oxygen isotope ratios of A. tepida and $H$. germanica tests do not show a clear spatial trend. In the upper estuary, the oxygen isotope values of these species show large differences between spring 2006 and winter 2007. Both species show heavier $\delta^{18} \mathrm{O}$ values by about $0.8 \%$ in spring 2006 compared to winter 2007. Surprisingly, in the lower estuary, the $\delta^{18} \mathrm{O}$ of $A$. tepida shows
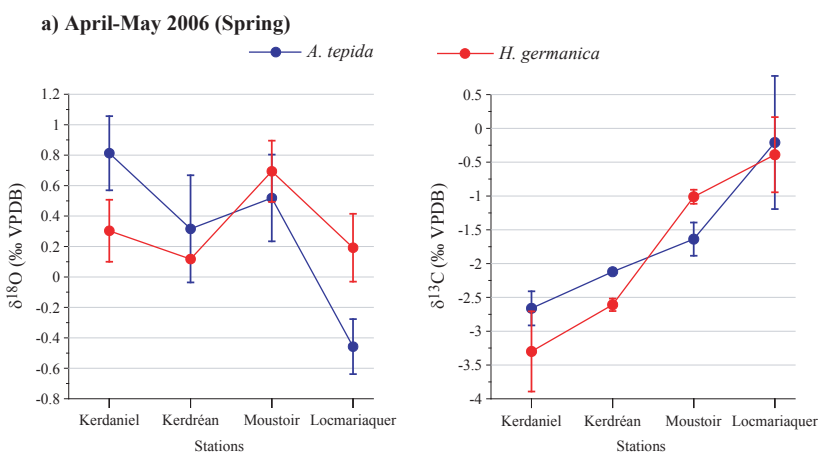

b) February 2007 (Winter)
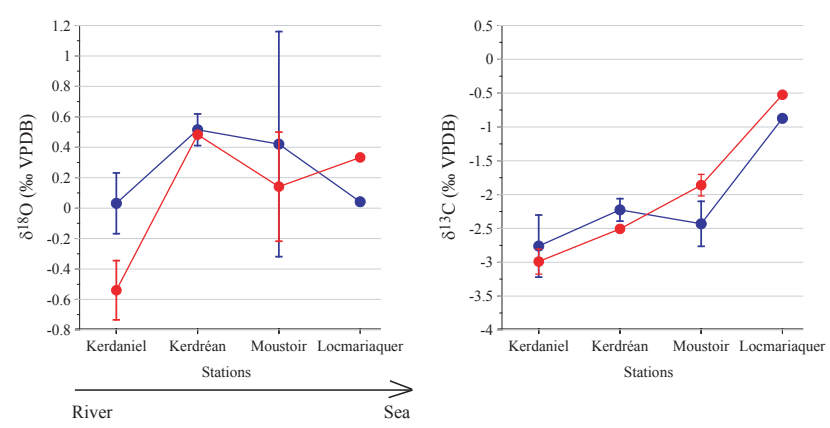

Fig. 5. Carbon and oxygen isotopic composition of A. tepida (blue) and $H$. germanica (red) in the Auray River estuary in spring 2006 (a) and winter 2007 (b) expressed by the mean and the standard deviation. Isotopic measurements are indicated in Table 1.

rather low values in spring 2006. At Locmariaquer $\delta^{18} \mathrm{O}$ is about $1 \%$ lower than at the other three stations. At the same station, spring 2006 values are about $0.5 \%$ o depleted in comparison to winter 2007 values (Fig. 5). H. germanica does not show such a clear $\delta^{18} \mathrm{O}$ minimum at Locmariaquer in spring 2006. In the middle estuary oxygen isotope composition of A. tepida and $H$. germanica remain fairly similar and do not show substantial changes between sampling periods.

The temperature gradient between upper and lower estuary is negligible at both sampling times (Fig. 2a). Consequently, we expected to find an increasing trend in the $\delta^{18} \mathrm{O}$ of benthic foraminifera from upper to lower parts of the estuary in response to decreasing fresh water influence (Fig. 3). This gradient should have been steeper in winter, when the salinity gradient between upper and the lower estuary is at a maximum, and reduced in spring when the salinity gradient is weaker (Fig. 2b). However, this is not observed, which suggests that the oxygen isotopic composition of benthic foraminifera in the Auray estuary does not represent the temperature and $\delta^{18} \mathrm{O}_{w}$ signatures at the time of sampling. 


\section{Discussion}

\subsection{Benthic foraminiferal stable isotopes $\left(\delta^{18} \mathrm{O}\right.$ and $\left.\delta^{13} \mathbf{C}\right)$ in subtidal environments}

High spatial and temporal variability of the physical parameters (temperature and salinity) complicate the interpretation of the isotopic composition of benthic foraminiferal shells in subtidal environments. Moreover, the highly complex ecology of the foraminiferal faunas excludes a straightforward application of stable isotopes to estimate temperature or salinity variations in subtidal estuaries. However, by combining foraminiferal stable isotopes and the annual Temperature (T) and Salinity (S) cycle, presented together

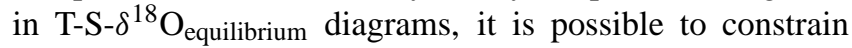
foraminiferal calcification seasons. Previously, similar diagrams have been used in paleoceanographic studies in open ocean settings to separate water masses (e.g., Zahn and Mix, 1991; Labeyrie et al., 1992; Zahn et al., 1997). Our approach is novel in that we combine the water mass mixing (i.e., salinity) with the annual temperature cycle. This approach is particularly well suited for the interpretation of stable isotopes in shallow water environments.

Theoretical $\delta^{18} \mathrm{O}_{e q}$ fractionation lines are calculated from water $\delta^{18} \mathrm{O}\left(\delta^{18} \mathrm{O}_{w}\right)$ and temperature (T) according to the paleotemperature equation of Shackleton (1974): $\mathrm{T}=16.9-4.38$ $\left(\delta^{18} \mathrm{O}_{e q}-\delta^{18} \mathrm{O}_{w}\right)+0.1\left(\delta^{18} \mathrm{O}_{e q}-\delta^{18} \mathrm{O}_{w}\right)^{2}$. The $\delta^{18} \mathrm{O}_{w}$ values are based on the $\delta^{18} \mathrm{O}_{w}$ : salinity relationship described in the results section $\left(\delta^{18} \mathrm{O}_{w}(\%\right.$ VSMOW $)=-4.565+$ 0.1416 Salinity) for the Auray River estuary. Standard mean ocean water $\delta^{18} \mathrm{O}_{w}$ (VSMOW) was converted to PDB units $\delta^{18} \mathrm{O}_{w}$ (VPDB) using the factor conversion of Hut (1987; $-0.27)$. Subsequently water temperature and salinity measurements (Fig. 2a, b) from Bono and Locmariaquer hydrographic stations (Fig. 1) have been averaged for 15-day intervals, from March 2006 to March 2008. The calculated values have been plotted in the T-S- $\delta^{18} \mathrm{O}_{e q}$ diagram. The diagram clearly shows the annual cycle of theoretical $\delta^{18} \mathrm{O}_{\text {calcite }}$ in the upper (e.g., Fig. 6a) and lower (e.g., Fig. 6e) estuary. The seasonal succession of calculated $\delta^{18} \mathrm{O}_{e q}$. is more differentiated in the upper part of the estuary where large seasonal changes in salinity result in a clear separation between cooler and low salinity winter waters and warmer and higher salinity late spring to autumn waters (e.g., Fig. 6a). Conversely, the seasonal cycle in the lower parts of the estuary is less differentiated and mainly determined by temperature changes (e.g., Fig. 6e).

The $\delta^{18} \mathrm{O}$ values of A. tepida and $H$. germanica (Table 1) are plotted in the T-S- $\delta{ }^{18} \mathrm{O}_{e q}$ diagrams as lines based on the $\delta^{18} \mathrm{O}_{e q}$ fractionation which represents unique combinations of temperature and salinity values. In case several isotopic measurements have been performed for the same sample a "band" representing the range of measured values is shown. The possible calcification periods are indicated by the overlap between these lines/bands and the areas repre- senting the seasonal $\delta^{18} \mathrm{O}_{e q}$ signature. Isotopic data from the upper (Kerdaniel) and middle/upper (Kerdréan) estuary are compared with the $\mathrm{T}$ and $\mathrm{S}$ data measured at Bono (Fig. 6ad), whereas isotopic data from the lower estuary (Locmariaquer) are compared to the $\mathrm{T}$ and $\mathrm{S}$ values of Locmariaquer Fig. (6e-f). No comparison is presented for the middle/lower estuary (Moustoir) since T-S records are not available for this part of the estuary.

The T-S- $\delta{ }^{18} \mathrm{O}_{e q}$ diagrams (Fig. 6) indicate that in many cases there is no unique solution but several calcification periods are feasible. In the upper estuary (Kerdaniel and Kerdreán) Ammonia tepida sampled in Spring 2006 and Winter 2007 may have calcified in spring, winter or autumn (Fig. 6ad). The same applies to H. germanica except for the specimens collected in Kerdaniel in winter 2007 which can only have calcified in spring or early summer. In the lower estuary (Locmariaquer) $H$. germanica and A. tepida may have calcified in autumn, summer or spring (Fig. 6e-f) with the exception of the specimens collected in spring 2006 which have an isotopic signature typical of summer conditions (Fig. 6e).

The $\delta^{13} \mathrm{C}_{\text {DIC }}$ values of Auray River water show a positive linear relation to salinity (Fig. 3). The observed spatial trend in benthic foraminiferal $\delta^{13} \mathrm{C}$ agrees well with the expected $\delta^{13} \mathrm{C}_{\text {DIC }}$ gradient caused by mixing of sea and river waters (Fig. 3). Therefore, by combining T-S- $\delta^{18} \mathrm{O}_{e q}$ diagrams with additional salinity constraints provided by carbon isotopes (last column in Table 2) we can reduce the number of possible calcification periods.

Subtidal areas of the Auray River estuary are characterized by organic rich sediments. It can therefore not be excluded that oxidation of isotopically light organic matter contributes to the carbon isotopic composition of A. tepida and $H$. germanica shells. However, the average spatial gradient of foraminiferal $\delta^{13} \mathrm{C}$ (around 2.9\%o, Table 1) between the upper and lower estuary corresponds to the expected $\delta^{13} \mathrm{C}_{\mathrm{DIC}}$ gradient in function of a 10 salinity change (Fig. 3). Therefore, the contribution of ${ }^{13} \mathrm{C}$ depleted DIC by organic matter degradation is probably small in our case. Consequently, although it is not possible to directly translate $\delta^{13} \mathrm{C}$ into a salinity value, we can use the carbon isotopic signature to rule out some of the theoretically possible calcification periods in the $\mathrm{T}-\mathrm{S}-\delta^{18} \mathrm{O}_{e q}$ diagram.

In the upper estuary (Kerdaniel and Kerdreán) calcification during autumn can be excluded for both sampling periods and both species because their $\delta^{13} \mathrm{C}$ indicates low salinity during calcification. Consequently, both species can only have calcified in winter or early spring. The restricted salinity range in the lower parts of the estuary makes the distinction between spring and autumn calcification more difficult (Fig. 6e-f). Although the carbon isotopic signatures are in line with the observations in the T-S- $\delta^{18} \mathrm{O}_{e q}$ diagram we can not use them to further constrain calcification periods.

A summary of the most likely timing of foraminiferal calcification in the Auray estuary is presented in Table 2. In the upper estuary both species calcified in winter or early 


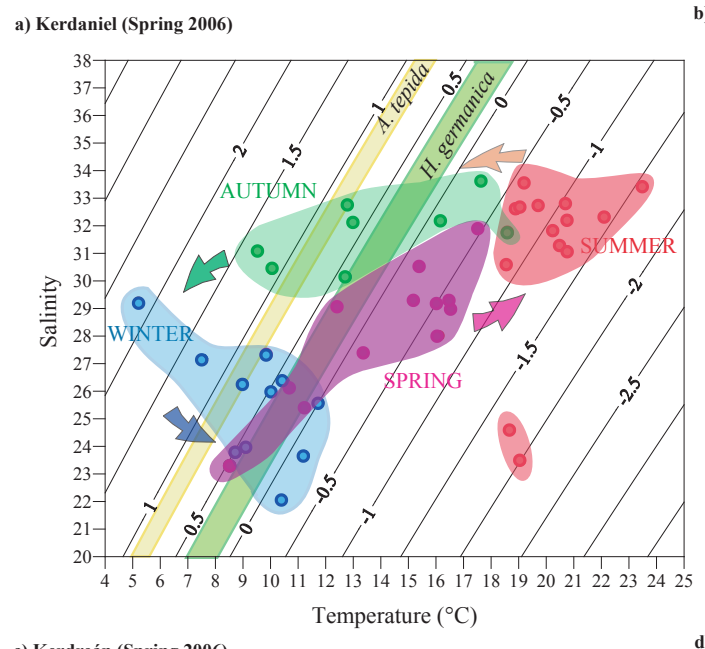

b) Kerdaniel (Winter 2007)
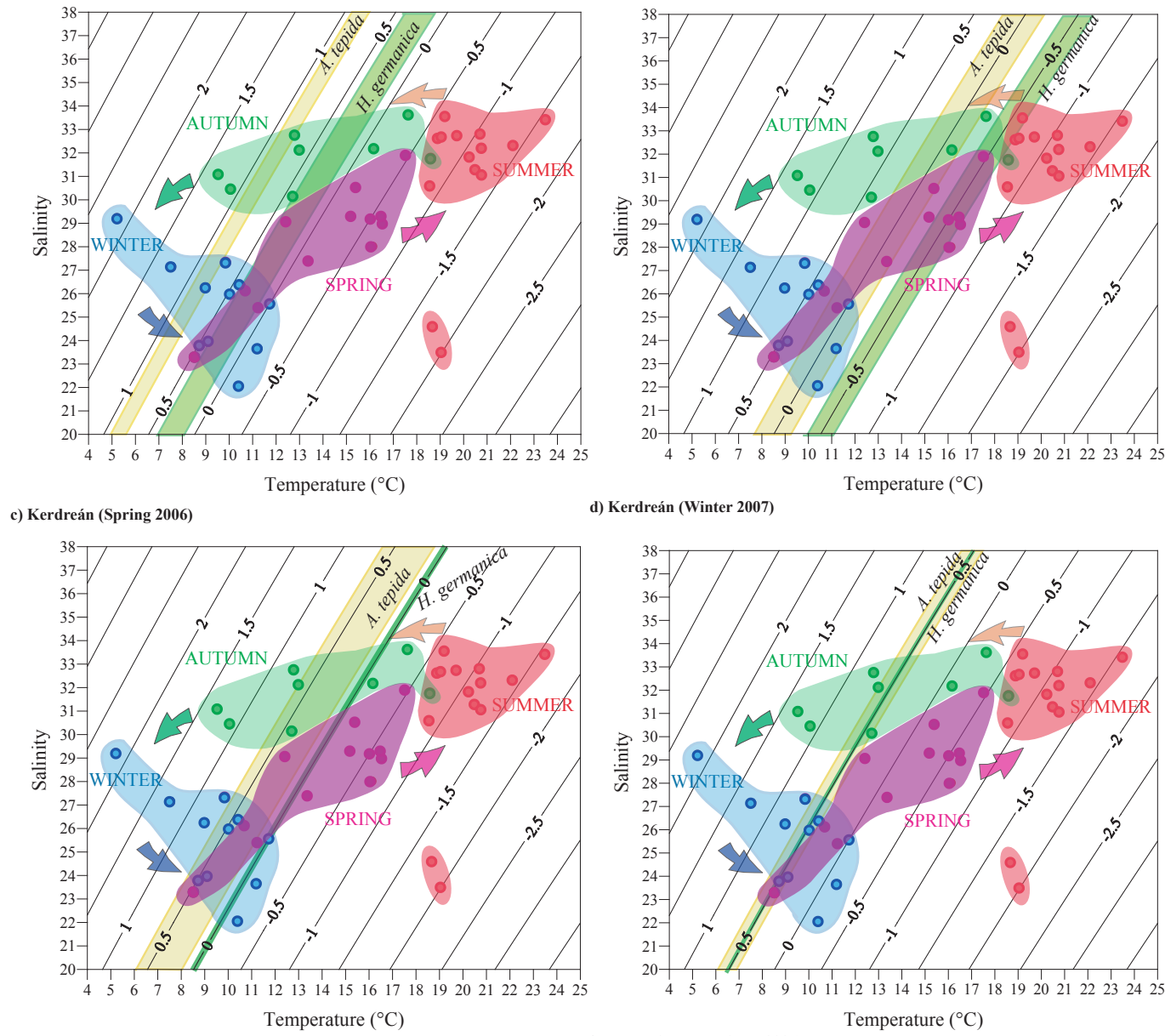

d) Kerdreán (Winter 2007)

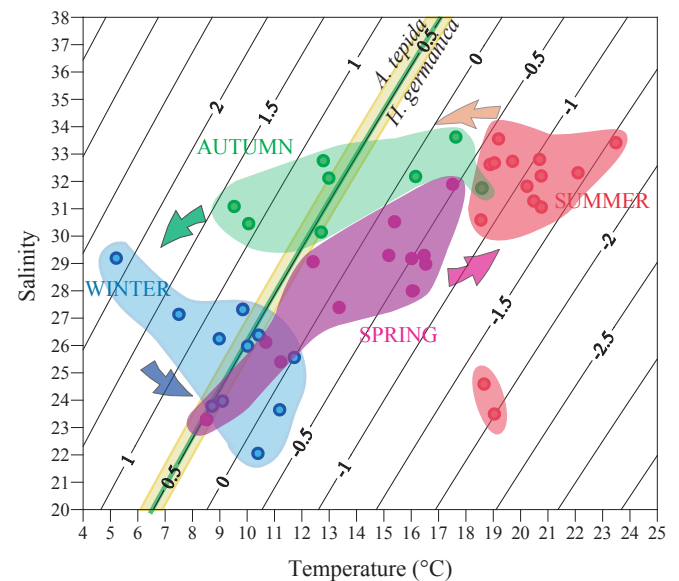

e) Locmariaquer (Spring 2006)

f) Locmariaquer (Winter 2007)
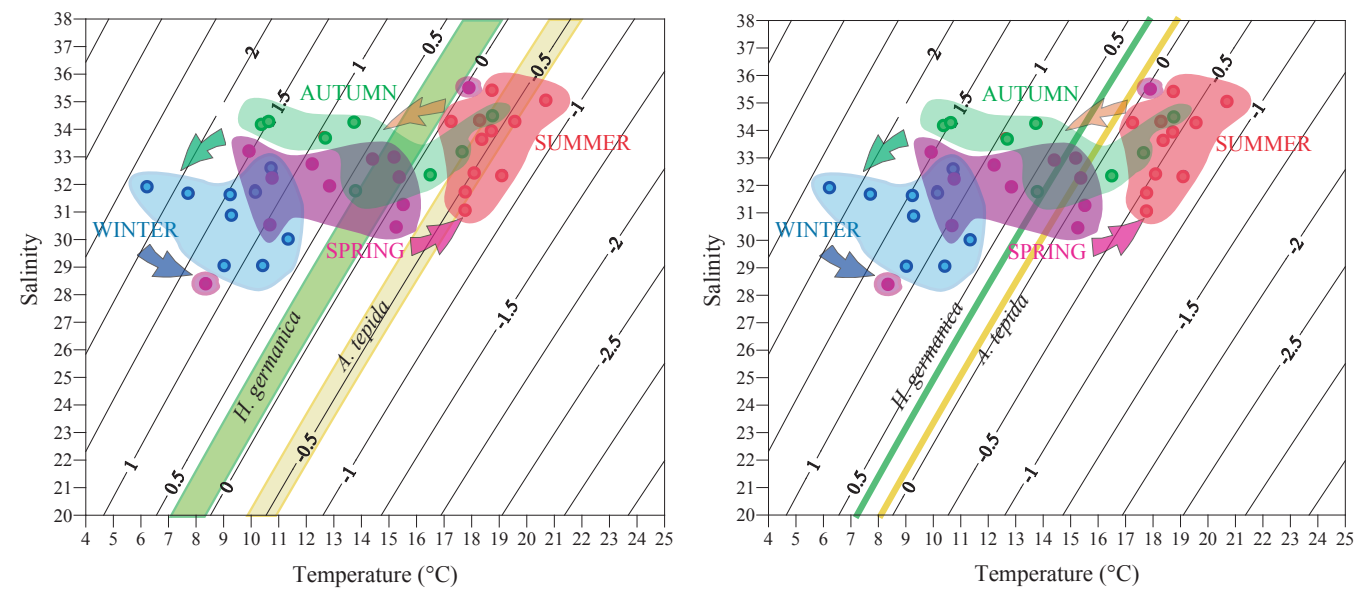

Fig. 6. T-S- $\delta^{18} \mathrm{O}_{e q}$ diagrams for the Auray River estuary and calcification periods of A. tepida and H. germanica at Kerdaniel (a-b), Kerdréan (c-d) and Locmariaquer (e-f). The $\delta^{18} \mathrm{O}_{e q}$ isolines are calculated according to the paleotemperature equation of Shackleton (1974) and the $\delta^{18} \mathrm{O}_{w}$ : salinity relationship for the Auray estuary (see main text). Bottom water temperature and salinity data averaged for 15 -day periods are indicated by circles. Colours indicate the different seasons. Benthic foraminiferal $\delta^{18} \mathrm{O}$ values (Table 1) are plotted in the diagrams as lines, yellow for A. tepida and green for H. germanica. In case several isotopic measurements have been performed for the same sample a "band" representing the range of measured values is shown. Possible calcification periods are indicated by the overlap of benthic foraminiferal $\delta^{18} \mathrm{O}$ values with the annual $\delta^{18} \mathrm{O}_{e q}$ cycle. 
Table 2. Calcification periods of A. tepida and H. germanica in the Auray River estuary. The possible calcification periods are indicated in Fig. 6 by the overlap between the $\delta^{18} \mathrm{O}$ foraminiferal values and the areas representing the seasonal $\delta^{18} \mathrm{O}_{e q}$ signature. Bold represent the most feasible calcification periods based in the carbon isotopic signature of benthic foraminifera $\left({ }^{\mathrm{a}}\right)$.

\begin{tabular}{|c|c|c|c|c|}
\hline Station & Species & Sampling period & Calcification periods & Salinity ${ }^{\mathrm{a}}$ \\
\hline \multirow[t]{4}{*}{ Kerdaniel } & \multirow[t]{2}{*}{ A. tepida } & April 2006, May 2006 & Autumn, winter & $21-22$ \\
\hline & & February 2007 & Autumn, winter, early spring & $19-23$ \\
\hline & \multirow[t]{2}{*}{ H. germanica } & April 2006, May 2006 & Autumn, winter, early spring & $17-20$ \\
\hline & & February 2007 & Late spring, summer & $20-21$ \\
\hline \multirow[t]{4}{*}{ Kerdréan } & \multirow[t]{2}{*}{ A. tepida } & April 2006, May 2006 & Autumn, winter, early spring & 24 \\
\hline & & February 2007 & Autumn, winter, early spring & $23-24$ \\
\hline & \multirow[t]{2}{*}{ H. germanica } & April 2006, May 2006 & Autumn, winter, early spring & $21-22$ \\
\hline & & February 2007 & Autumn, winter, early spring & 22 \\
\hline \multirow{4}{*}{ Locmariaquer } & \multirow{2}{*}{ A. tepida } & April 2006, May 2006 & Summer & $28-34$ \\
\hline & & February 2007 & Spring, summer, autumn & 29 \\
\hline & \multirow[t]{2}{*}{ H. germanica } & April 2006, May 2006 & Spring, summer, autumn & 33 \\
\hline & & February 2007 & Spring, summer, autumn & 30 \\
\hline
\end{tabular}

a Salinity estimates from the carbon isotopic composition of A. tepida and H. germanica. Estimations are based on the assumption that benthic foraminiferal $\delta^{13} \mathrm{C}$ is mainly a function of mixing between sea water and river water (Fig. 3).

spring. In the lower estuary $H$. germanica calcified in spring or in autumn, whereas A. tepida most probably calcified in summer (samples collected in spring 2006) or in summer, autumn or spring (samples collected in winter 2007). Therefore, benthic foraminifera calcified from a few months to half a year (or even more) before sampling. This is particularly true for samples collected in February 2007 in Locmariaquer. In this area benthic foraminifera calcified more than half a year before the collection time. Although the life cycle of benthic foraminifera may be longer than one year (Murray, 1991), their reproduction and growth is limited to a relatively short period, possibly related to favourable environmental conditions. Laboratory experiments demonstrate that A. tepida can quickly grow to an adult size in 20 and 120 days depending on temperature, salinity and food availability (Bradshaw, 1957, 1961). Results of Bradshaw (1957) and unpublished observations in our laboratory indicate that after growing to adult size, chamber addition in A. tepida becomes slower as the individual grows larger. Culturing experiments also demonstrated that under suboptimal environmental conditions (e.g., $10^{\circ} \mathrm{C}$, Bradshaw, 1957), this species can remain alive for long periods without growing or reproducing. In nature, dormancy has been suggested as survival strategy under adverse conditions such as anoxia (Bernhard and SenGupta, 1999; Gustafsson and Nordberg, 1999; Polovodova et al., 2009). It is not impossible for episodic hypoxia events to occur in the muddy organic-rich environments of the upper and middle areas of the Auray estuary. Preferential calcification during warmer months in the lower estuary is probably related to the ecological preferences of the studied species. The lower part of the estuary is probably not the optimal habitat for H. germanica and A.tepida, as is shown by their low abundances (Fig. 4b, c). It appears that these taxa only reproduce in the outer estuary during short periods of the year which may coincide with peaks in phytoplankton production in spring and summer (Paulmier, 1972). In the rest of the estuary, the most favourable calcification periods coincide with the colder months and/or early spring. Foraminiferal reproduction peaks in winter and in early spring have been reported in the nearby Bay of Bourgneuf (Morvan et al., 2006; Debenay et al., 2006).

\subsection{Constraints of the approach and future applications}

Systematic offsets between the isotopic composition of the foraminiferal shell and the surrounding waters are usually explained as vital effects, which may be the combined effect of multitude of processes (see reviews in Grossman, 1987; Rohling and Cooke, 1999). The consequence is that only few benthic foraminiferal taxa precipitate their shells in equilibrium. To our knowledge, there are no published data available on the isotopic disequilibria for the two species used here- Ammonia tepida and Haynesina germanica. A small isotopic offset from equilibrium fractionation would shift the lines of the T-S- $\delta^{18} \mathrm{O}_{e q}$ plots but would not substantially change the interpretation of our data.

Tidal currents likely transport some live benthic foraminifera from more open marine settings into the estuary and vice versa. We consider transport of shells not to have substantially affected the spatial distribution of H. germanica and/or A. tepida. If foraminifera from the outer parts of the estuary were transported to the upper and middle parts, we should find lighter $\delta^{18} \mathrm{O}$ ratios indicative of calcification during the warm season. Additionally, because of their contrasting isotopic signature, we can exclude that specimens collected at Locmariaquer originated from sites in the upper estuary. 
Stable isotopic measurements in the Auray estuary represent the average of several individuals which may have calcified in different periods of the year. Isotopic measurements of individual foraminifera would make it possible not only to estimate the calcification period of each single specimen but also to reconstruct the seasonal ranges of temperature and salinity on the basis of fossil assemblages.

Results obtained in this study show clearly that in subtidal environments, high spatial and temporal variability of the environmental parameters as well as benthic foraminiferal assemblages seriously hamper the application of oxygen and carbon isotope geochemistry for environmental reconstructions. In these extremely variable environments, timing of foraminiferal calcification has a profound impact on the $\delta^{18} \mathrm{O}$ of the shells. Here we show that different calcification periods apply to different species, in different parts of the estuary. Although stable isotopes have been used in brackish marine environments to reconstruct paleosalinity over time scales varying from centuries (Thomas et al., 2000; Scheurle and Hebbeln, 2003) to thousands of years (Winn et al., 1998; Kim and Kennett, 1998; Polyak et al., 2003; Peros et al., 2007), it is obvious that the reconstructing salinity or temperature in these settings needs additional constraints from independent proxies (Polyak et al., 2003; Peros et al., 2007).

Acknowledgements. This work is a contribution to the PaleoSalt project funded by the European Science Foundation (ESF) under the EUROCORES Programme EuroCLIMATE through contract number ERAS-CT-2003-980409 of the European Commission, DG Research, FP 02. The authors are grateful to Arnold van Dijk for running the isotope analysis and to all participants in the sampling cruises; Fabrice Redois, Gerald Duchemin, Sophie Terrien and Hélené Howa from Angers University and Evelyne Goulbert from Vannes University. We are especially thankful to E. Goulbert for proving us with the gravity core. The comments and suggestions of E. Geslin and C. Barras in an early version of this manuscript are sincerely acknowledged. P. D. and E. L. were funded by a postdoctoral grant from the Conseil Général of the Vendée (France). This manuscript benefited from the comments and suggestions of $\mathrm{E}$. Thomas and an anonymous reviewer.

Edited by: S. W. A. Naqvi

\section{References}

Alve, E.: Benthic foraminiferal responses to estuarine pollution: a review, J. Foramin. Res., 25, 190-203, 1995.

Alve, E. and Murray, J. W.: Temporal variability in vertical distributions of live (stained) intertidal foraminifera, southern England, J. Foramin. Res., 31, 12-24, 2001.

Armynot du Châtelet, E., Debenay, J.-P., and Soulard, R.: Foraminiferal proxies for pollution monitoring in moderately polluted harbors, Environ. Pollut., 127, 27-40, 2004.

Aucour, A.-M., Sheppard, S. M. F., and Savoye, R.: $\delta^{13}$ C of fluvial mollusk shells (Rhône River): A proxy for dissolved inorganic carbon?, Limnol. Oceanogr., 48, 2186-2193, 2003.
Bauch, H. A., Erlenkeuser, H., Bauch, D., Mueller-Lupp, T., and Taldenkova, E.: Stable oxygen and carbon isotopes in modern benthic foraminifera from the Laptev Sea shelf: implications for reconstructing proglacial and profluvial environments in the Arctic, Mar. Micropaleontol., 51, 285-300, 2004.

Bernhard, J. M. and Sen Gupta, B. K.: Foraminifera of oxygendepleted environments, in: Modern Foraminifera, edited by: Sen Gupta, B. K., Kluwer Academic Publishers, London, UK, 201216, 1999.

Boltovskoy, E. and Lena, H.: Seasonal occurrences, standing crop and production in benthic foraminifera of Puerto Deseado, Contributions from the Cushman Foundation for Foraminiferal Research, 20, 87-95, 1969.

Bouchet, V. M. P., Debenay, J. P., Sauriau, P.-G., Radford-Knoery, J., and Soletchnike, P.: Effects of short-term environmental disturbances on living benthic foraminifera during the Pacific oyster summer mortality in the Marennes-Oléron Bay (France), Mar. Environ. Res., 64, 358-383, 2007.

Bradshaw, J. S.: Laboratory studies on the rate of growth of the foraminifer, "Streblus beccarii (Linné) var. tepida (Cushman)", J. Paleontol., 31, 1138-1147, 1957.

Bradshaw, J. S.: Laboratory experiments on the ecology of foraminifera, Contributions from the Cushman Foundation for Foraminiferal Research, 12, 87-106, 1961.

Buzas, M. A., Hayek, L.-A., Reed, S. A., and Jett, J. A.: Foraminiferal densities over five years in the Indian River Lagoon, Florida: A model of pulsating patches, J. Foramin. Res., 32, 68-93, 2002.

Cearreta, A.: Distribution and ecology of benthic foraminifera in the Santoña estuary, Spain, Revista Española de Paleontología, 3, 23-38, 1988.

Chandler, G. T., Williams, D. F., Spero, H. J., and Xiaodong, G.: Sediment microhabitat effect on carbon stable isotopic signatures of microcosm-cultured benthic foraminifera, Limnol. Oceanogr., 41, 680-688, 1996.

Cronin, T. M., Thunell, R., Dwryer, G. S., Saenger, C., Mann, M. E., Vann, C., and Seal II, R. R.: Multiproxy evidence of Holocene climate variability from estuarine sediments, eastern North America, Paleoceanography, 20, PA4006, doi:10.1029/2005PA001145, 2005.

Debenay, J.-P., Guillou, J.-J., Redois, F., and Geslin, E.: Distribution trends of foraminiferal assemblages in paralic environments: a base for using foraminifera as bioindicators, in: Environmental Micropaleontology. The application of microfossils to environmental geology, edited by: Martin, J. E., Topics in Geobiology, Kluwer Academic/Plenum Publishers, New York, USA, 39-67, 2000.

Debenay, J.-P., Tsakiridis, E., Soulard, R., and Grossel, H.: Factors determining the distribution of foraminiferal assemblages in Port Joinville Harbor (Ile d'Yeu, France): the influence of pollution, Mar. Micropaleontol., 43, 75-118, 2001.

Debenay, J.-P., Bicchi, E., Goubert, E., and Amynot du Châtelet, E.: Spatio-temporal distribution of benthic foraminifera in relation to estuarine dynamics (Vie estuary, Vendée, W France), Estuar. Coast. Shelf Sci., 67, 181-197, 2006.

Duchemin, G., Jorissen, F. J., Redois, F., and Debenay, J.-P.: Foraminiferal microhabitats in a high marsh: Consequences for reconstructing past sea levels, Palaeogeogr. Palaeocl., 226, 167$185,2005$. 
Gillikin, D. P., and Bouillon, S.: Determination of $\delta^{18} \mathrm{O}$ of water and $\delta^{13} \mathrm{C}$ of dissolved inorganic carbon using a simple modification of an elemental analyzer-isotope ratio mass spectrometer: an evaluation, Rapid Commun. Mass Spectrom., 21, 1475-1478, 2007.

Grossman, E. L.: Stable isotopes in modern benthic foraminifera: a study of vital effect, J. Foramin. Res., 17, 48-61, 1987.

Gustafsson, M., and Nordberg, K.: Benthic foraminifera and their response to hydrography, periodic hypoxic conditions and primary production in the Koljö fjord on the Swedish west coast, J. Sea Res., 41 163-178, 1999.

Hippensteel, S. P., Martin, R. E., Nikita, D., and Pizzuto, J. E.: Interannual variation of marsh foraminiferal assemblages (Bombay Hook National Wildlife Refuge, Smyrna, De): Do foraminifera assemblages have a memory?, J. Foramin. Res., 32, 97-100, 2000.

Hohenegger, J., Piller, W. E., and Baal, C.: Horizontal and vertical spatial microdistribution of foraminifers in the shallow subtidal Gulf of Trieste, Northern Adriatic Sea, J. Foramin. Res., 23, 79 $101,1993$.

Hut, G.: Stable Isotope Reference Samples for Geochemical and Hydrological Investigations, in: Report on Consultants' Meeting, Vienna, 16-18 September 1985, edited by: Hut, G., IAEA, Vienna, Austria, 1987.

IAEA/WMO: Global Network of Isotopes in Precipitation. The GNIP Database, 2006.

Kim, J.-M. and Kennett, J. P.: Paleoenvironmental changes associated with the Holocene marine transgression, Yellow Sea (Hwanghae), Mar. Micropaleont., 34, 71-89, 1998.

Labeyrie, L. D., Duplessy, J.-C., Duprat, J., Juillet-Leclerc, A., Moyes, J., Michel, E., Kallel, N., and Shackleton, N. J.: Changes in the vertical structure of the North Atlantic Ocean between glacial and modern times, Quat. Sci. Rev., 11, 401-414, 1992.

Le Cadre, V. and Debenay, J.-P.: Morphological and cytological responses of Ammonia (foraminifera) to copper contamination: Implication for the use of foraminifera as bioindicators of pollution, Environ. Pollut., 143, 304-317, 2006.

Leorri, E., Cearreta, A., Irabien, M. J., and Yusta, I.: Geochemical and microfaunal proxies to assess environmental quality conditions during the recovery process of a heavily polluted estuary: The Bilbao estuary case (N. Spain), Sci. Total Environ., 396, 1227, 2008.

Leorri, E. and Cearreta, A.: Quantitative assessment of the salinity gradient within the estuarine systems in the southern Bay of Biscay using benthic foraminifera, Cont. Shelf Res., 29, 1226-1239, 2009.

McGann, M.: High-resolution foraminiferal, isotopic, and trace element records from Holocene estuarine deposits of San Francisco bay, California, J. Coastal Res., 24, 1092-1109, 2008.

Miyajima, T., Yamada, Y., Hanba, Y. T., Yoshii, K., Koitabashi, T., and Wada, E.: Determinig the stable isotope ratio of total dissolved inorganic carbon in lake water by GC/C/IRMS, Limnol. Oceanogr., 40, 994-1000, 1995.

Morvan, J., Le Cadre, V., Jorissen, F., and Debenay, J.-P.: Foraminifera as potentiql bio-indicators of the "Erika" oil spill in the Bay of Bourgneuf: Field and experimental studies, Aquat. Living Resour., 17, 317-322, 2004.

Morvan, J., Debenay, J.-P., Jorissen, F., Redois, F., Bénéteau, E., Delplancke, M., and Amato, A.-S.: Patchiness and life cycle of intertidal foraminifera: Implication for environmental and paleoenvironmental interpretation, Mar. Micropaleontol., 61, 131$151,2006$.

Murray, J. W.: Ecology and Palaeoecology of benthic foraminifera, Longman Scientific \& Technical, Essex (UK), 397 pp., 1991.

Murray, J. W.: When does environmental variability become environmental change? The proxy record of benthic foraminifera, in: Environmental Micropaleontology. The application of microfossils to environmental geology, edited by: Martin, J. E., Topics in Geobiology, Kluwer Academic/Plenum Publishers, New York, USA, 7-37, 2000.

Murray, J. W., and Alve, E.: Major aspects of foraminiferal variability (standing crop and biomass) on a monthly scale in an intertidal zone, J. Foramin. Res., 30, 177-191, 2000.

Murray, J. W.: Ecology and Applications of Benthic Foraminifera, Cambridge University Press, Cambridge (UK), 426 pp., 2006.

Paulmier, G.: Seston-phytoplancton et microbenthos en riviere d'Auray leur role dans le cycle biologique des huitres (Ostrea edulis L.), Revue des Travaux des Pêches Maritimes (ISTPM), 36, 375-506, 1972.

Peros, M. C., Reinhardt, E. G., Schwarcz, H. P., and Davis, A. M.: High-resolution paleosalintiy reconstruction from Laguna de la Leche, north coastal Cuba, using Sr, O, and C isotopes, Palaeogeogr. Palaeocl., 245, 535-550, 2007.

Platon, E., Sen Gupta, B. K., Rabalais, N. N., and Turner, R. E.: Effect of seasonal hypoxia on the benthic foraminiferal community of the Louisiana inner continenatal shelf: the 20th century record, Mar. Micropaleont., 54, 263-283, 2005.

Polovodova, I., Nikulina, A., Schönfeld, J., and Dullo, W. C.: Recent benthic foraminifera in the Flensburg Fjord (Western Baltic Sea), J. Micropalaeontol., 28, 1-14, 2009.

Polyak, L., Stanovoy, V., and Lubinski, D. J.: Stable isotopes in benthic foraminiferal calcite from a river-influenced Arctic marine environment, Kara and Pechora Seas, Paleoceanography, 18(1), 1003, doi:10.1029/2001PA000752, 2003.

Redois, F. and Debenay, J.-P.: Influence du confinement sur la répartition des foraminiferes benthiques: exemple de l'estran d'une ria mesotidal de Bretagne méridional, Revue de Paléobiologie, 15, 243-260, 1996.

Reinhardt, E. G., Fitton, R. J., and Schwarcz, H. P.: Isotopic (Sr, $\mathrm{O}, \mathrm{C}$ ) indicators of salinity and taphonomy in marginal marine environments, J. Foramin. Res., 33, 262-272, 2003.

Rohling, E. J. and Cooke, S.: Stable oxygen and carbon isotopes in foraminiferal carbonate shells, in: Modern Foraminifera, edited by: Sen Gupta, B. K., Kluwer Academic Publishers, Cornwall, 239-258, 1999.

Scheurle, C. and Hebbeln, D.: Stable oxygen isotopes as recorders of salinity and river discharge in the German Bight, North Sea, Geo-Mar. Lett., 23, 130-136, 2003.

Shackleton, N. J.: Attainment of isotopic equilibrium between ocean water and the benthonic genus Uvigerina; Isotopic changes in the ocean during the last glacial, Colloques Internationaux du C.N.R.S., 219, 203-219, 1974.

Swallow, J. E.: Intra-annual variability and patchiness in living assemblages of salt-marsh foraminifera from Mill Rythe Creek, Chichester Harbour, England, J. Micropaleontol., 19, 9-22, 2000.

Thomas, E., Gapotchenko, T., Varekamp, J. C., Mecray, E. L., and Buchholtz ten Brink, M. R.: Benthic foraminifera and environ- 
mental changes in Long Island Sound, J. Coastal Res., 16, 641$655,2000$.

Winn, K., Erlenkeuser, H., Nordberg, K., and Gustafsson, M.: Paleohydrography of the Great Belt, Denmark, during the Littorina Transgression: the isotope signal, Meyniana, 50, 237-251, 1998.

Zahn, R. and Mix, A. C.: Benthic foraminiferal $\delta^{18} \mathrm{O}$ in the ocean's temperature-salinity-density field: constraints on ice age thermohaline circulation, Paleoceanography, 6, 1-20, 1991.
Zahn, R., Schönfeld, J., Kudrass, H.-R., Park, M.-H., Erlenkeuser, H., and Grootes, P.: Thermohaline instability in the North Atlantic during meltwater events: stable isotope and ice-rafted detritus records from core SO75-26KL, Portuguese margin, Paleoceanography, 12, 696-710, 1997. 